\title{
Bioactivity Assessment of Indian Origin-Mangrove Actinobacteria against Candida albicans
}

\author{
J. G. S. Pavan Kumar ${ }^{1}$, Ajitha Gomathi ${ }^{1}$, Vitor Vasconcelos ${ }^{2,3, *}$ and K. M. Gothandam ${ }^{1}$ (D) \\ 1 Department of Biotechnology, School of Biosciences and Technology, VIT University, Vellore 632014, India; \\ pavankumarup6@gmail.com (J.G.S.P.K.); aji.mku@gmail.com (A.G.); gothandam@gmail.com (K.M.G.) \\ 2 CIIMAR/CIMAR - Interdisciplinary Centre of Marine and Environmental Research, University of Porto, \\ Terminal de Cruzeiros do Porto de Leixões, 4450-208 Matosinhos, Portugal \\ 3 Department of Biology, Faculty of Sciences, University of Porto, 4069-007 Porto, Portugal \\ * Correspondence: vmvascon@fc.up.pt; Tel.: +351-223401817
}

Received: 27 December 2017; Accepted: 9 February 2018; Published: 12 February 2018

\begin{abstract}
Actinobacteria is found to have a potent metabolic activity against pathogens. The present study reveals the assessment of potent antifungal secondary metabolites from actinobacteria isolated from Indian marine mangrove sediments. The samples were collected from the coastal regions of Muthupet, Andaman and the Nicobar Islands. Identification was carried out using $16 \mathrm{~S}$ rRNA analysis and biosynthetic genes (Polyketide synthase type I/II and Non-ribosomal peptide synthase) were screened. Actinobacteria were assayed for their antifungal activity against 16 clinical Candida albicans and the compound analysis was performed using gas chromatography-mass spectrometry GC-MS. The 31 actinobacterial strains were isolated and 16S rRNA gene sequencing revealed that this ecosystem is rich on actinobacteria, with Streptomyces as the predominant genus. The PCR based screening of biosynthetic genes revealed the presence of PKS-I in six strains, PKS-II in four strains and NRPS in 11 strains. The isolated actinobacteria VITGAP240 and VITGAP241 (two isolates) were found to have a potential antifungal activity against all the tested C. albicans. GC-MS results revealed that the actinobacterial compounds were belonging to heterocyclic, polyketides and peptides. Overall, the strains possess a wide spectrum of antifungal properties which affords the production of significant bioactive metabolites as potential antibiotics.
\end{abstract}

Keywords: actinobacteria; antifungal; polyketide synthase; non ribosomal peptide synthase; Candida albicans

\section{Introduction}

Bacterial cell factories and their wide applications in search of added value products such as molecular therapeutics is booming currently; they have a promising future as the safest and most efficient medicinal product discovery [1]. Flora and fauna as well as microorganisms are good sources to obtain a wide variety of natural medicinal products [2,3]. Actinobacteria are very significant in this regard [4], taken into account their intrinsic pharmacological importance [5]. The secondary metabolites produced by these gram positive bacteria, have a wide spectrum of activities such as antimicrobial, antiviral, immune-modulatory and as anticancer agents [6]. Peptides and polyketides are noticeable and they are a potential group of natural products, mainly synthesized by two major types of enzymes: non-ribosomal peptide synthases (NRPS) and polyketide synthases (PKS) [7]. Microbes harbouring these biosynthetic gene clusters are probable source of novel natural products. Polyketides have extensive applications as antibiotics in the pharmaceutical industry [8]. With several classes of PKS genes known, type I PKS encompasses multidomain enzymes and type II PKS is comprised of many enzymes [9]. NRPS are modular enzymes with multiple domains, namely acetylation, condensation, and thioesterase [10]. Analysing the biosynthetic genes depicts the potential of the microbe to produce 
a particular type of natural product [11]. Moreover, gene guided metabolite studies also help in the avoidance of the redundant discovery of known compounds [12]. These genes have served to be a great source of interesting natural products with pharmacological relevance [1].

Apart from traditional techniques, such as identification or screening of pharmacologically important microbes isolated from various ecosystems, the 16S rRNA phylogenetic analysis seems to be an efficient method to point out medicinally important actinomycetes [13]. Mangrove ecosystems are very promising sources of actinobacteria [14]. These microorganisms have been identified as producers of antimicrobial compounds including cypemycin, neomycin, bottromycins, chloramphenicol and grisemycin [15]. In fact, our current research aimed to identify actinomycetes with antifungal properties. Referring to few previous reports [16,17], the present work focuses on identifying microbial leads for antifungal metabolite production and to screen the isolates for the presence of biosynthetic genes. The result reveals the occurrence of secondary metabolite genes in the majority of the isolates and enunciates their great probability in biosynthesizing novel metabolites, hence prioritizing the isolates for natural product discovery.

\section{Results}

\subsection{Isolation and Identification of Mangrove Actinobacteria}

From 10 marine sediment samples collected, approximately 31 actinobacterial isolates were isolated and characterized. Figure 1 illustrates the isolation and morphology of the strains. Table 1 lists the strains obtained in this study along with the sampling location. From each of the sampling sites, sediments from different spots were collected to study the diversity and abundance of the organisms. In this study, 31 strains have been isolated from Muthupet (6 isolates) and from Andaman and the Nicobar Islands (25 isolates). Identification of the strains was done by $16 \mathrm{~S}$ rDNA gene sequencing using the primers $27 \mathrm{~F}$ and 1492R. Most of the actinobacteria isolated were found to fall under Streptomyces genus, while few of the strains were of the genera Rhodococcus (1), Corynebacterineae (1) and Actinomycetales (1). Significantly, the strains listed in Table 2 were identified as novel species based on the blast similarity of $16 \mathrm{SrDNA}$ gene sequences. In our study, among all media used, Starch casein agar media proved to be effective for the isolation of actinobacteria.

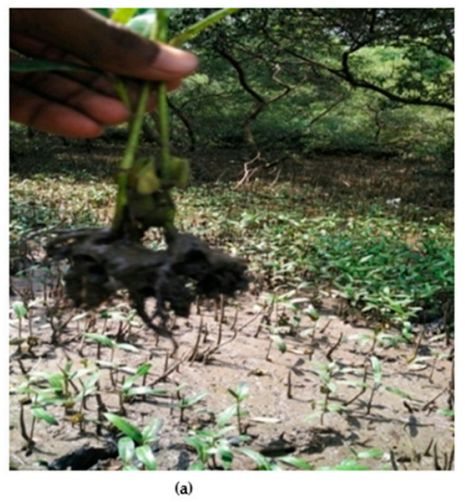

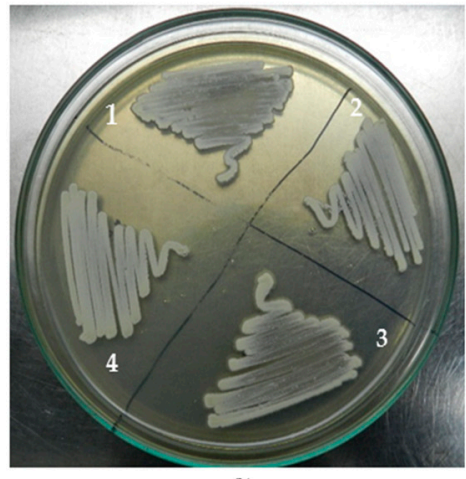

(b)

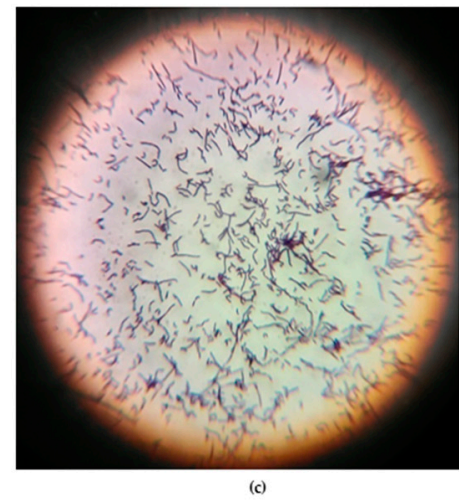

(c)

Figure 1. (a) Sampling of mangrove sediments; (b) Pure culture of Actinobacteria: 1. VITGAP080, 2. VITGAP240, 3. VITGAP241, 4. VITGAP258; (c) Gram staining of Streptomyces albidoflavus (VITGAP241). 
Table 1. Isolates obtained in this study and their accession ID.

\begin{tabular}{|c|c|c|c|c|}
\hline Sequence-ID & Genbank Accession Numbers & Organism & Sampling Location & Latitude and Longitude \\
\hline VITGAP080 & KY608546 & Streptomyces rochei & Muthupet, Thiruvarur, Tamil Nadu & $10.39 \mathrm{~N}, 79.49 \mathrm{E}$ \\
\hline VITGAP095 & KY608547 & Streptomyces variabilis & Muthupet, Thiruvarur, Tamil Nadu & $10.39 \mathrm{~N}, 79.49 \mathrm{E}$ \\
\hline VITGAP103 & KY608548 & Streptomyces sp. & Muthupet, Thiruvarur, Tamil Nadu & $10.39 \mathrm{~N}, 79.49 \mathrm{E}$ \\
\hline VITGAP104 & KY608549 & Streptomyces sp. & Muthupet, Thiruvarur, Tamil Nadu & $10.39 \mathrm{~N}, 79.49 \mathrm{E}$ \\
\hline VITGAP105 & KY608550 & Streptomyces sp. & Muthupet, Thiruvarur, Tamil Nadu & $10.39 \mathrm{~N}, 79.49 \mathrm{E}$ \\
\hline VITGAP229 & KY608585 & Streptomyces sp. & Port Mout, Andaman and Nicobar Islands & $11.40 \mathrm{~N}, 92.41 \mathrm{E}$ \\
\hline VITGAP231 & KY608586 & Streptomyces sp. & Port Mout, Andaman and Nicobar Islands & $11.40 \mathrm{~N}, 92.41 \mathrm{E}$ \\
\hline VITGAP232 & KY608587 & Streptomyces sp. & Port Mout, Andaman and Nicobar Islands & $11.40 \mathrm{~N}, 92.41 \mathrm{E}$ \\
\hline VITGAP233 & KY608588 & Streptomyces clavuligerus & Port Mout, Andaman and Nicobar Islands & $11.40 \mathrm{~N}, 92.41 \mathrm{E}$ \\
\hline VITGAP235 & KY608589 & Streptomyces sp. & Port Mout, Andaman and Nicobar Islands & $11.40 \mathrm{~N}, 92.41 \mathrm{E}$ \\
\hline VITGAP238 & KY608590 & Streptomyces sp. & Port Mout, Andaman and Nicobar Islands & $11.40 \mathrm{~N}, 92.41 \mathrm{E}$ \\
\hline VITGAP240 & KY608591 & Streptomyces lividans & Corbyn, Andaman and Nicobar Islands & $11.38 \mathrm{~N}, 92.44 \mathrm{E}$ \\
\hline VITGAP241 & KY608592 & Streptomyces albidoflavus & Corbyn, Andaman and Nicobar Islands & $11.38 \mathrm{~N}, 92.44 \mathrm{E}$ \\
\hline VITGAP242 & KY608593 & Streptomyces sp. & Corbyn, Andaman and Nicobar Islands & $11.38 \mathrm{~N}, 92.44 \mathrm{E}$ \\
\hline VITGAP244 & KY608594 & Rhodococcus sp. & Corbyn, Andaman and Nicobar Islands & $11.38 \mathrm{~N}, 92.44 \mathrm{E}$ \\
\hline VITGAP245 & KY608595 & Streptomyces violascens & Corbyn, Andaman and Nicobar Islands & $11.38 \mathrm{~N}, 92.44 \mathrm{E}$ \\
\hline VITGAP246 & KY608596 & Corynebacterineae bacterium & Corbyn, Andaman and Nicobar Islands & $11.38 \mathrm{~N}, 92.44 \mathrm{E}$ \\
\hline VITGAP247 & KY608597 & Streptomyces sp. & Sippighat, Andaman and Nicobar Islands & $11.36 \mathrm{~N}, 92.41 \mathrm{E}$ \\
\hline VITGAP248 & KY608598 & Streptomyces sp. & Sippighat, Andaman and Nicobar Islands & $11.36 \mathrm{~N}, 92.41 \mathrm{E}$ \\
\hline VITGAP250 & KY608599 & Streptomyces sp. & Sippighat, Andaman and Nicobar Islands & $11.36 \mathrm{~N}, 92.41 \mathrm{E}$ \\
\hline VITGAP253 & KY608600 & Streptomyces sp. & Wandoor Jetty, Andaman and Nicobar Islands & $11.35 \mathrm{~N}, 92.37 \mathrm{E}$ \\
\hline VITGAP255 & KY608601 & Actinomycetales bacterium & Burmanalla, Andaman and Nicobar Islands & $11.33 \mathrm{~N}, 92.43 \mathrm{E}$ \\
\hline VITGAP256 & KY608602 & Streptomyces sp. & Burmanalla, Andaman and Nicobar Islands & $11.33 \mathrm{~N}, 92.43 \mathrm{E}$ \\
\hline VITGAP257 & KY608603 & Streptomyces sp. & Burmanalla, Andaman and Nicobar Islands & $11.33 \mathrm{~N}, 92.43 \mathrm{E}$ \\
\hline VITGAP258 & KY608604 & Streptomyces sp. & Burmanalla, Andaman and Nicobar Islands & $11.33 \mathrm{~N}, 92.43 \mathrm{E}$ \\
\hline VITGAP259 & KY608605 & Actinomycetales bacterium & Burmanalla, Andaman and Nicobar Islands & $11.33 \mathrm{~N}, 92.43 \mathrm{E}$ \\
\hline VITGAP261 & KY608606 & Streptomyces sp. & Burmanalla, Andaman and Nicobar Islands & $11.33 \mathrm{~N}, 92.43 \mathrm{E}$ \\
\hline VITGAP263 & KY608607 & Streptomyces chumphonensis & Burmanalla, Andaman and Nicobar Islands & $11.33 \mathrm{~N}, 92.43 \mathrm{E}$ \\
\hline VITGAP270 & KY608608 & Streptomyces sp. & MundaPahad, Andaman and Nicobar Islands & $11.29 \mathrm{~N}, 92.42 \mathrm{E}$ \\
\hline VITGAP271 & KY608609 & Streptomyces sp. & Kalapahad, Andaman and Nicobar Islands & $11.36 \mathrm{~N}, 92.40 \mathrm{E}$ \\
\hline
\end{tabular}


Table 2. Novel actinobacterial strains obtained in this study; $16 \mathrm{~S}$ rDNAgene sequence similarities.

\begin{tabular}{|c|c|c|c|c|c|}
\hline Isolate No. & Genbank Accession No. of the Isolates & Sampling Location of the Isolates & Closest Organism & Genebank No. & Similarity Percentage \\
\hline VITGAP080 & KY608546 & Muthupet, Thiruvarur, Tamil Nadu & Streptomyces rochei strain & KP823705 & $96 \%$ \\
\hline VITGAP095 & KY608547 & Muthupet, Thiruvarur, Tamil Nadu & Streptomyces variabilis & KU981101 & $95 \%$ \\
\hline VITGAP 103 & KY608548 & Muthupet, Thiruvarur, Tamil Nadu & Streptomyces sp. & СР013142 & $95 \%$ \\
\hline VITGAP 105 & KY608550 & Muthupet, Thiruvarur, Tamil Nadu & Streptomyces sp. & JQ009379 & $96 \%$ \\
\hline VITGAP 235 & KY608589 & Port Mout, Andaman and Nicobar Islands & Streptomyces sp. & KX279534 & $83 \%$ \\
\hline VITGAP 240 & KY608591 & Corbyn, Andaman and Nicobar Islands & Streptomyces violascens & KU973980 & $91 \%$ \\
\hline VITGAP 253 & KY608600 & Wandoor Jetty, Andaman and Nicobar Islands & Streptomyces sp. & KU884356 & $94 \%$ \\
\hline VITGAP 255 & KY608601 & Burmanalla, Andaman and Nicobar Islands & Actinomycetales bacterium & EU368818 & $88 \%$ \\
\hline VITGAP 257 & KY608603 & Burmanalla, Andaman and Nicobar Islands & Streptomyces sp. & JF736620 & $97 \%$ \\
\hline VITGAP 258 & KY608604 & Burmanalla, Andaman and Nicobar Islands & Streptomyces sp. & KR817750 & $87 \%$ \\
\hline VITGAP 261 & KY608606 & Burmanalla, Andaman and Nicobar Islands & Streptomyces sp. & KX928494 & $92 \%$ \\
\hline VITGAP 263 & KY608607 & Burmanalla, Andaman and Nicobar Islands & Streptomyces chumphonensis & NR_126175 & $94 \%$ \\
\hline VITGAP 271 & KY608609 & Kalapahad, Andaman and Nicobar Islands & Streptomyces sp. & KT588654 & $92 \%$ \\
\hline
\end{tabular}




\subsection{Genetic Screening}

PCR screening of the actinobacterial strains revealed the presence of PKS type I, PKS type II and NRPS biosynthetic genes. Amplicons of desired size [PKS type I (bp-1.2kb), PKS type II (bp-500bp), NRPS (bp-700bp)] shows the presence of the biosynthetic gene. Table 3 lists the biosynthetic genetic potential of the actinobacterial strains. Among the 31 strains obtained, only 14 strains showed the presence of type I PKS gene and 6 of the strains showed the presence of type II PKS gene. Interestingly, all strains harboring type II PKS were also found to harbor type I PKS.

The biosynthetic potential of the actinobacterial strains reveals that type I PKS are more abundant than that of type II. Type I PKS was found to be harbored by about $20.8 \%$ of the actinobacterial strains, while type II PKS was found only with $8.3 \%$. Remarkably, approximately $34.7 \%$ of strains showed the presence of NRPS gene. Almost all the strains harboring the genes belong to Streptomyces genus, while one of the strains revealing the presence of type I PKS is Rhodococcus. Interestingly, strains belonging to other genera, namely Corynebacterineae, did not harbor any of the studied genes.

Table 3. Biosynthetic potential of the actinobacterial isolates.

\begin{tabular}{cccc}
\hline Strains & PKS (Type I) & PKS (Type II) & NRPS \\
\hline VITGAP080 & + & + & + \\
VITGAP095 & & & + \\
VITGAP105 & & + & + \\
VITGAP240 & + & + & + \\
VITGAP241 & + & + & + \\
VITGAP242 & + & & + \\
VITGAP244 & + & & + \\
VITGAP248 & & & + \\
VITGAP250 & & & + \\
VITGAP253 & & & + \\
VITGAP255 & & & + \\
VITGAP257 & & & \\
VITGAP258 & + &
\end{tabular}

\subsection{Phylogenetic Analysis of the Actinobacteri Strains}

Phylogenetic analysis was performed by constructing the neighbor joining phylogenetic tree of all the strains to analyze the evolutionary relationship, and the distance was calculated by maximum-parsimony method using MEGA software (Figure 2). Based on the query coverage and the percentage of identity, the top aligned sequences were retrieved (Table 4). Significance of the branch order was determined by bootstrap analysis of 1000 replicates, see Figures 3-7 (These figures depict the evolutionary relationships of taxa of the query sequences NRPS (VITGAP241), Type I PKS (VITGAP-240, VITGAP-241) Type II PKS (VITGAP-240, VITGAP-241). The optimal tree with the sum of branch lengths for each sequence are 1.31645770, 1.25726471, 1.52648453, 4.16276907, and 16.20030581 respectively. The percentage of replicate trees in which the associated taxa clustered together in the bootstrap test (1000 replicates) are shown next to the branches. The tree is drawn to scale, with branch lengths in the same units as those of the evolutionary distances used to infer the phylogenetic tree. The analysis involved 16, 16, 14, 11 and 7 nucleotide sequences. Codon positions included were 1st + 2nd + 3rd + Noncoding). 


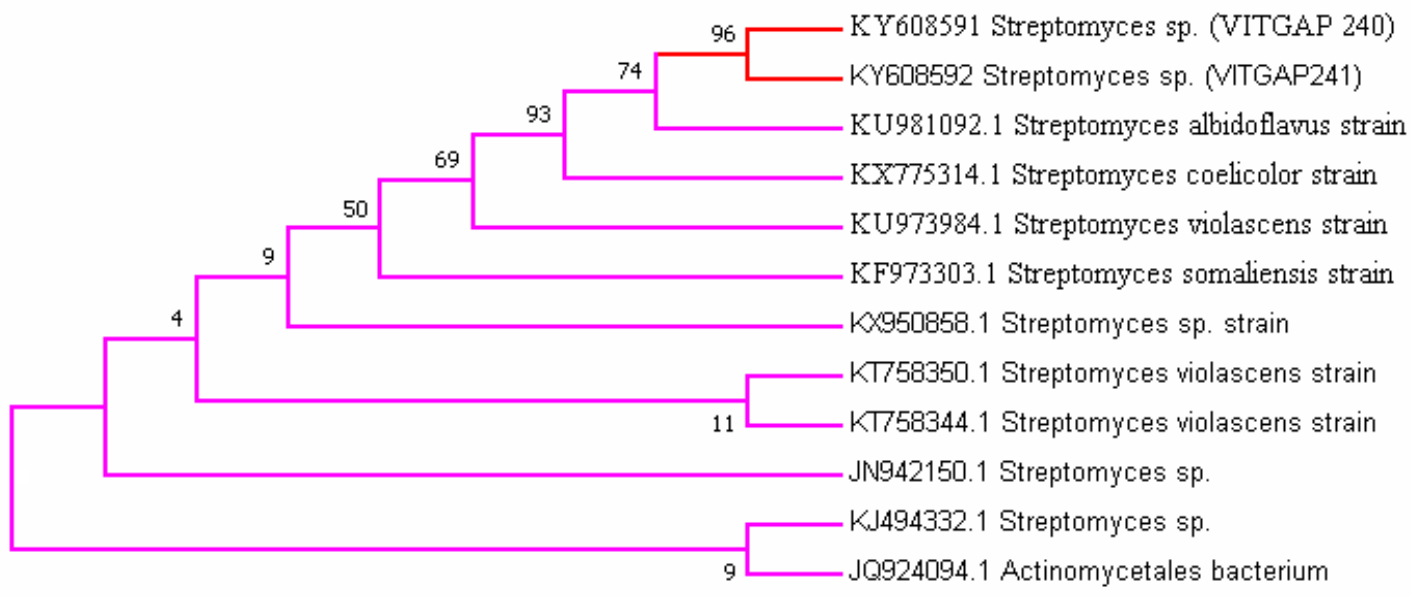

Figure 2. Phylogenetic tree based on 16S rRNA gene sequences of the strains.

Streptomyces sp. (VITGAP240 \& VITGAP241) share the conserved domain with a common ancestor. Actinomycetales bacterium is found be the new diverse species among the entire group of the Streptomyces family with minimum bootstrap value. Streptomyces $\mathrm{sp}$. in two clades are common along with their closely related species, Streptomyces violascens strain.

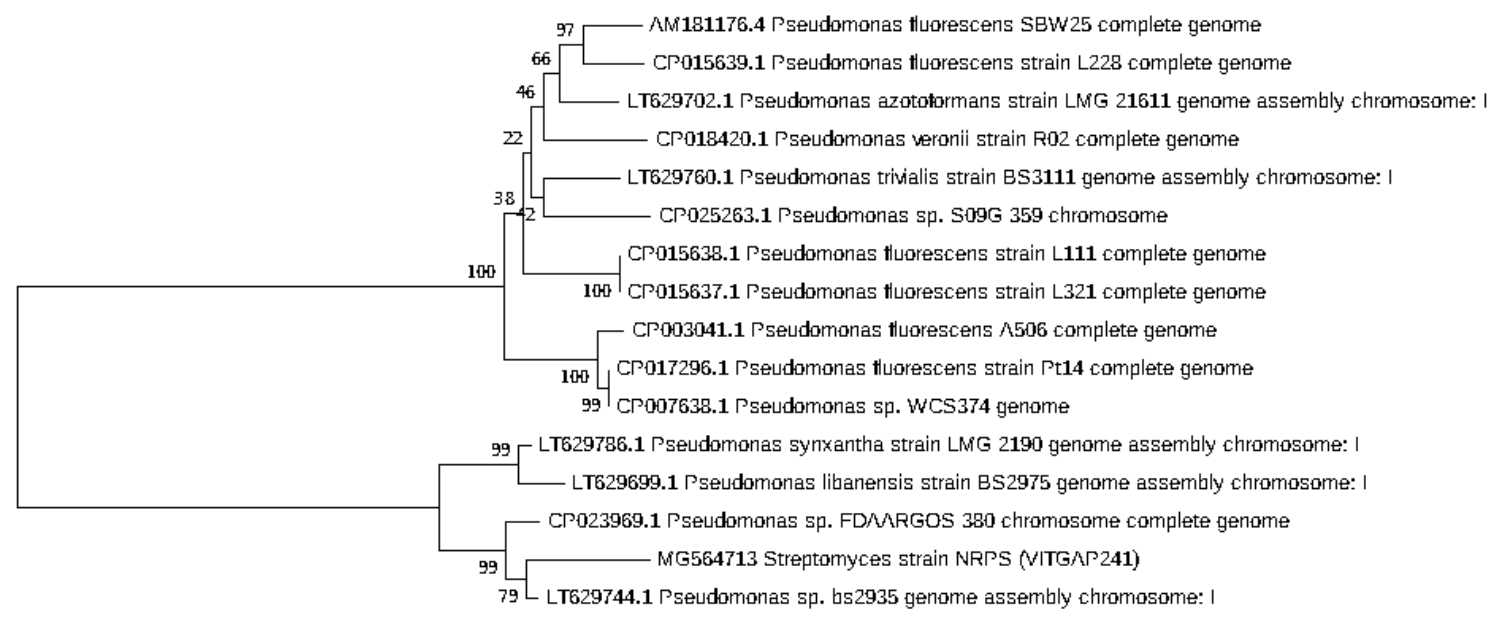

Figure 3. Dendrogram of NRPS (VITGAP241).

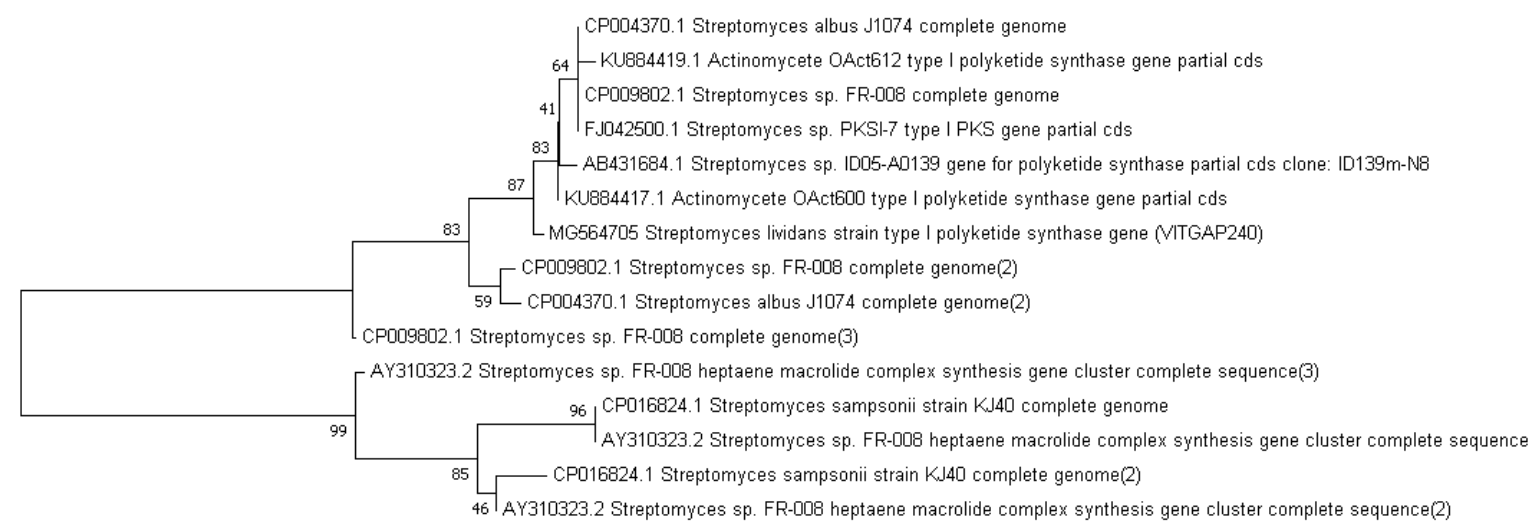

Figure 4. Dendrogram of Type I PKS (VITGAP240). 


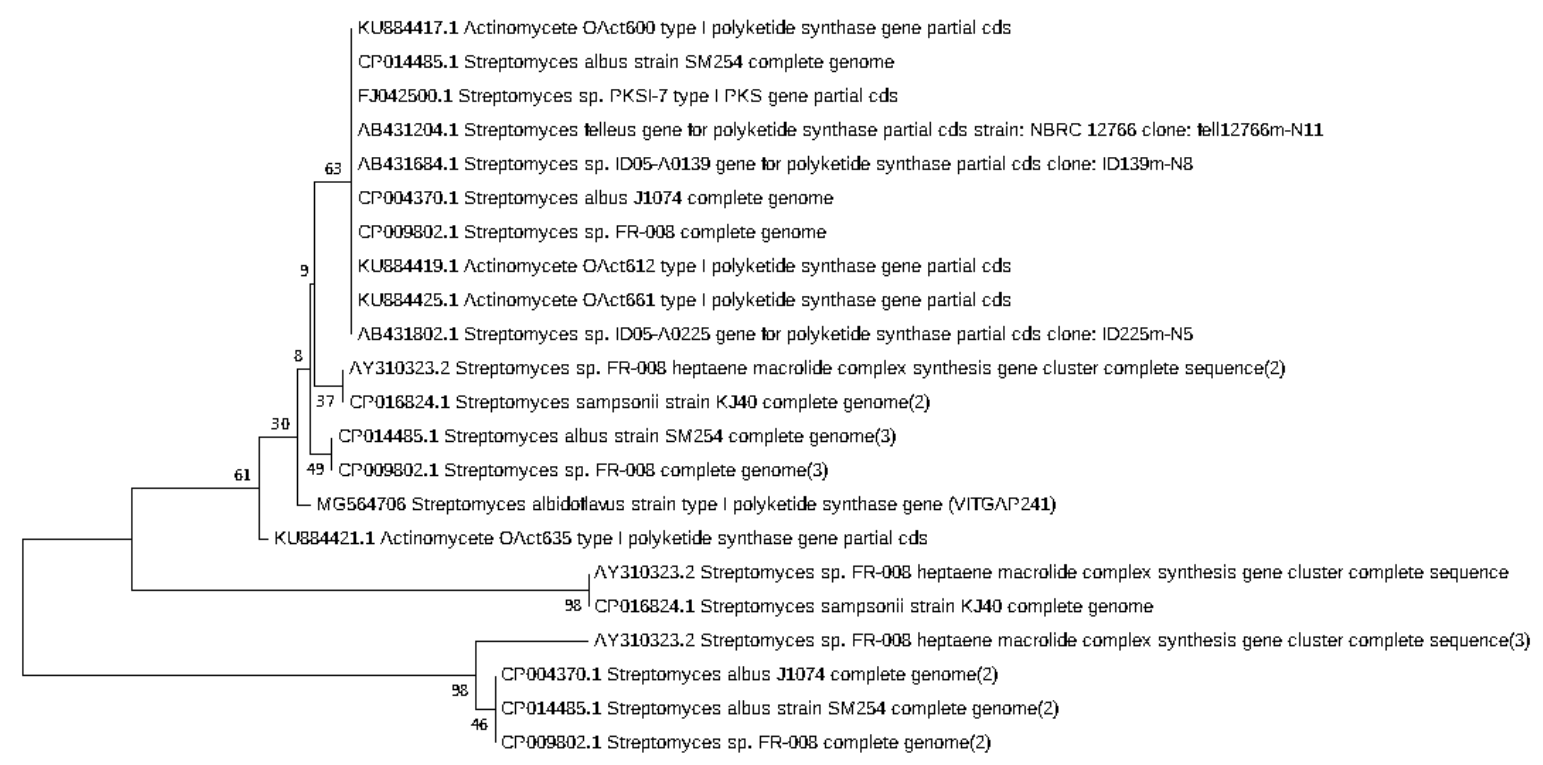

Figure 5. Dendrogram of Type I PKS (VITGAP241).

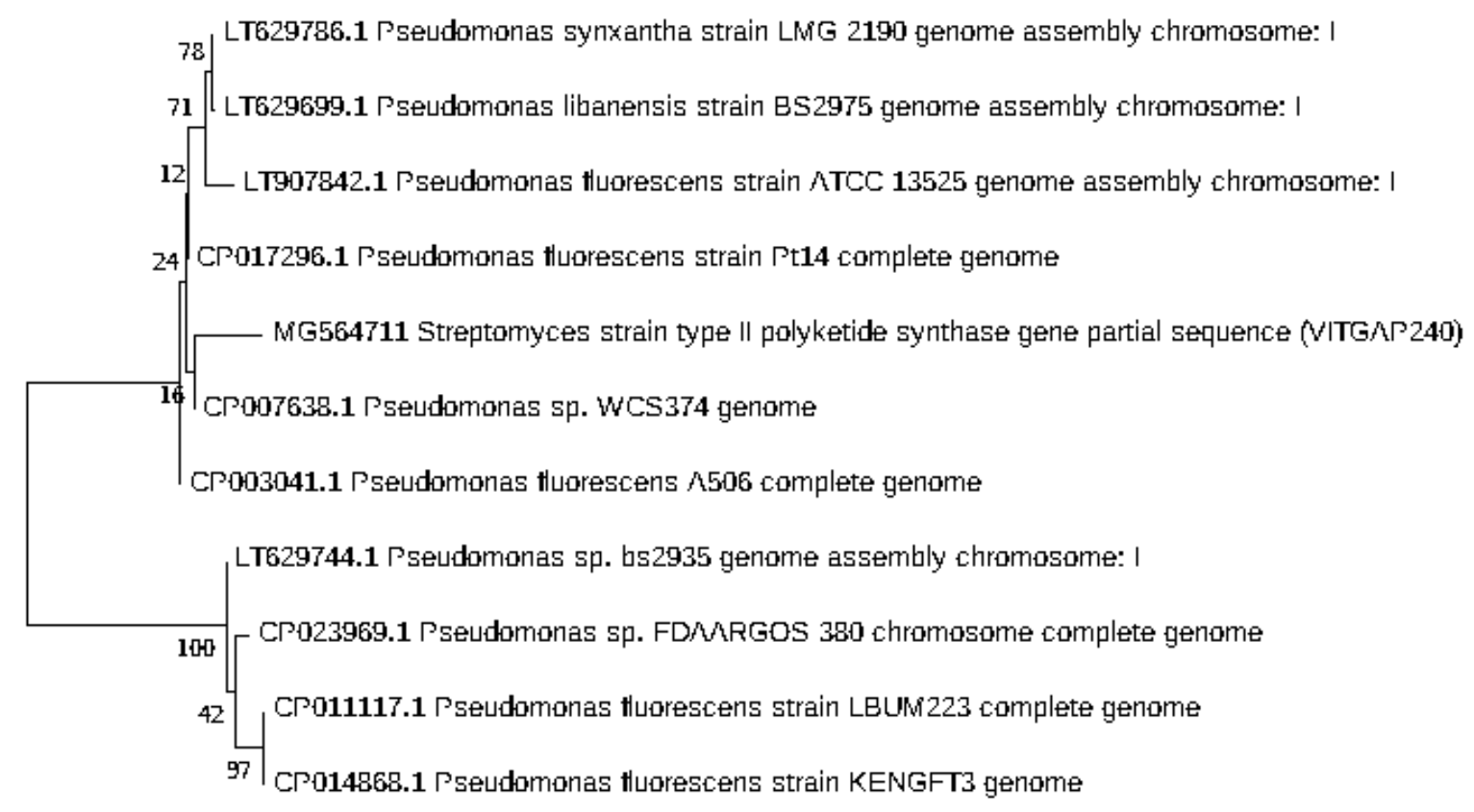

Figure 6. Dendrogram of Type II PKS (VITGAP240).

Table 4. Query coverage and percentage of identity of the sequences.

\begin{tabular}{cccc}
\hline Sequence & Query Coverage & \% of Identity & No of Hits \\
\hline NRPS_VITGAP241 & $99 \%$ & $>83 \%$ & 15 \\
Type I PKS VITGAP-240 & $99 \%$ & $>89 \%$ & 15 \\
Type I PKS VITGAP-241 & $80 \%$ & $>79 \%$ & 13 \\
Type II PKS VITGAP-240 & $56 \%$ & $>70 \%$ & 10 \\
Type II PKS VITGAP-241 & $68 \%$ & $>67 \%$ & 6 \\
\hline
\end{tabular}




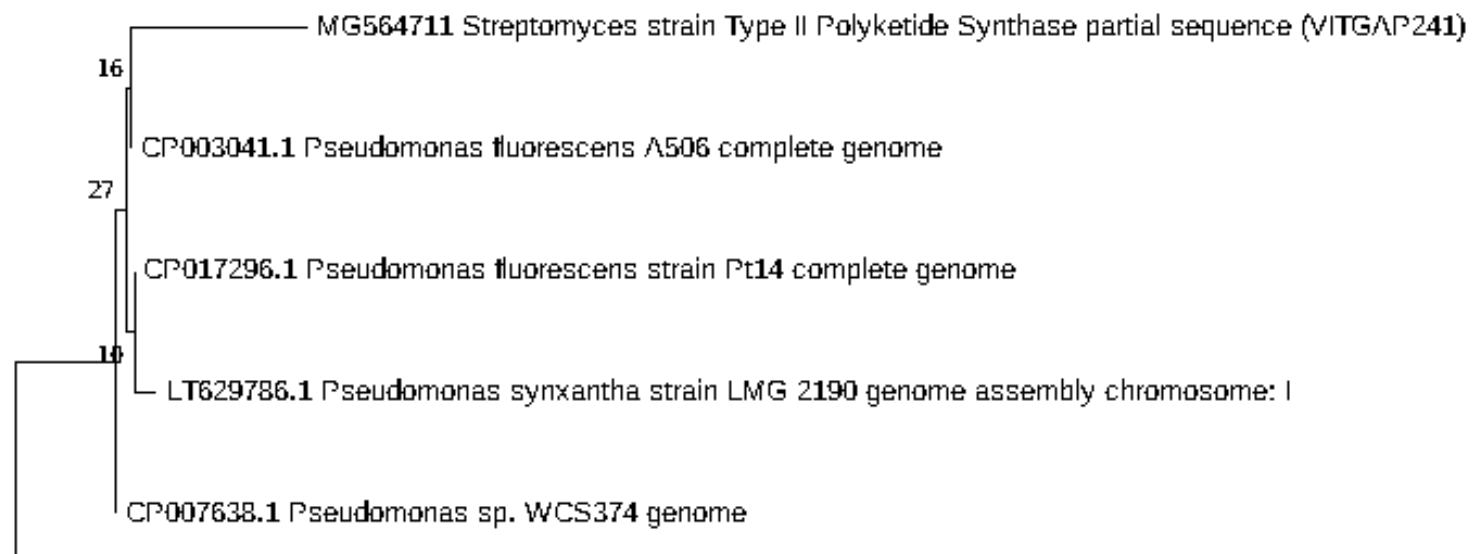

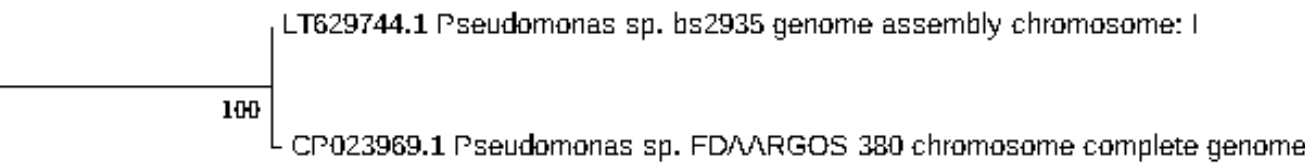

Figure 7. Dendrogram of Type II PKS (VITGAP241).

\subsection{Antifungal Activity Prospect Evaluations}

Actinobacterial strains harboring biosynthetic genes were tested for their antifungal activity against 16 clinical isolates of $C$. albicans obtained from diagnostic centers in Tiruchirappalli, Tamil Nadu, India. Among the 14 bio-potential strains, only 2 of them (VITGAP240 and VITGAP241) exhibited an effective anti-candidal activity against the tested pathogens. Interestingly, these two bioactive strains possessed both type I and II PKS genes, hence attracting further attention. VITGAP241 also showed the presence of the NRPS gene. VITGAP241 exhibited more pronounced activity (18 mm diameter) than VITGAP240 (13 mm diameter). Figure 8 illustrates the bioactivity of the strains VITGAP240 and VITGAP241.

Efficient antifungal activity was exhibited by the actinobacterial strains. As of our knowledge, this is the first report analyzing the antifungal potentiality of actinobacteria of Indian origin against Candida albicans (clinical pathogens). Though many of the strains possessing the genes were not functionally active, the two strains exhibiting bioactivity, harboured one of the biosynthetic genes supporting our hypothesis.
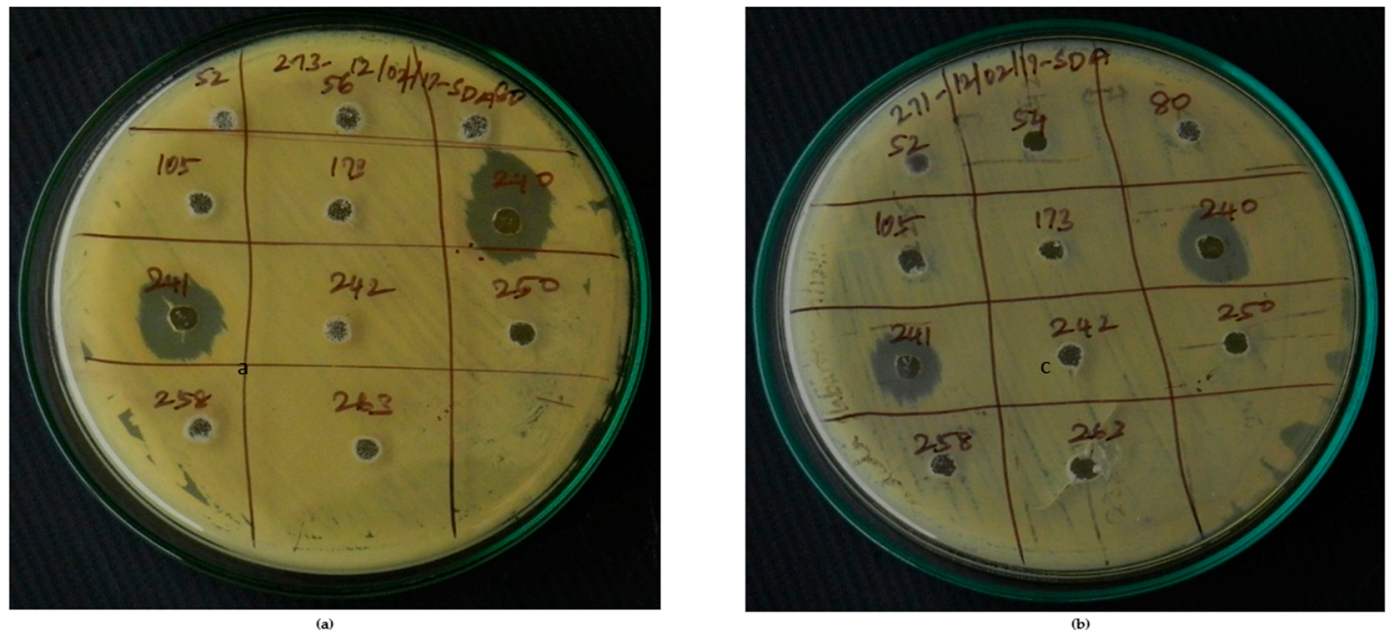

Figure 8. VITGAP240 \& VITGAP241 showing significant activity against: (a) Clinical isolate 1 of Candida albicans (b) Clinical isolate 2 of Candida albicans. 


\subsection{Antibiotic Sensitivity Assessment of Actinobacteria Strains}

To assess the antibiotic sensitivity, the strains were screened against the following antibiotics: piperacillin, co-trimoxazole, ofloxacin, amikacin, erthyromicin, cefuroxime, tobramycin, ampicillin, tetracycline, ceftriazone, polmycin, nitrofurantin, rifampicin, clindamycin, netillin, ceftrazidime, novobiocin, aztreonam, cephotaxine, chloramphenicol, streptomycin, penicillin, methicillin, jancomycin, gentamycin, and vancomycin (Table 5). Based on PCR screening (Table 3), the potential strains which harbored PKS and NRPS gene and a few strains which did not show the presence of the genes were also chosen randomly for the assay to compare the strains.

All the tested strains displayed significant sensitivity against most of the antibiotics used. The Highest sensitivity was obtained against netillin, novobiocin, cephotaxine ( $60 \%$ each), and lowest sensitivity was obtained against piperacillin, erthyromicin, nitrofurantin, chloramphenicol and jancomycin $(6.6 \%)$. The strains exhibited resistance against the following antibiotics: aztreonam, streptomycin, penicillin, and methicillin. The strain VITGAP240 exhibited resistance to the following antibiotics: piperacillin, amikacin, erthyromicin, cefuroxime, ampicillin, polmycin, nitrofurantin, rifampicin, clindamycin, ceftrazidime, aztreonam, chloramphenicol, streptomycin, penicillin, methicillin, jancomycin and gentamycin. The strain VITGAP241 exhibited resistance to piperacillin, ofloxacin, erthyromicin, cefuroxime, tobramycin, ampicillin, ceftriazone, polmycin, nitrofurantin, clindamycin, ceftrazidime, aztreonam, streptomycin, penicillin and methicillin. Hence, the strains VITGAP240 and VITGAP241 proved to be promising and pharmacological important targets for the future, especially for antifungal based secondary metabolite profiling studies.

Table 5. Antibiogram profile of the strains (R-resistant, S-sensitive).

\begin{tabular}{|c|c|c|c|c|c|c|c|c|c|c|c|c|c|c|c|}
\hline \multirow[t]{2}{*}{ Antibiotics } & \multicolumn{11}{|c|}{ Strains with the Biosynthetic Genes } & \multicolumn{4}{|c|}{$\begin{array}{l}\text { Strains without the } \\
\text { Biosynthetic Genes }\end{array}$} \\
\hline & 80 & 95 & 240 & 241 & 242 & 105 & 248 & 250 & 253 & 255 & 258 & 103 & 105 & 261 & 263 \\
\hline Piperacillin & $\mathrm{R}$ & $\mathrm{R}$ & $\mathrm{R}$ & $\mathrm{R}$ & $S$ & $\mathrm{R}$ & $\mathrm{R}$ & $\mathrm{R}$ & $\mathrm{R}$ & $\mathrm{R}$ & $\mathrm{R}$ & $\mathrm{R}$ & $\mathrm{R}$ & $\mathrm{R}$ & $\mathrm{R}$ \\
\hline Co-Trimoxazole & $\mathrm{R}$ & S & $S$ & S & $S$ & S & S & $\mathrm{S}$ & $\mathrm{R}$ & $\mathrm{R}$ & S & $\mathrm{R}$ & $\mathrm{R}$ & $\mathrm{R}$ & $\mathrm{R}$ \\
\hline Ofloxacin & $\mathrm{S}$ & $S$ & $S$ & $\mathrm{R}$ & $S$ & $\mathrm{R}$ & $S$ & $\mathrm{R}$ & $\mathrm{R}$ & S & $\mathrm{R}$ & $\mathrm{R}$ & $S$ & $\mathrm{~S}$ & $\mathrm{R}$ \\
\hline Amikacin & $\mathrm{S}$ & S & $\mathrm{R}$ & S & $S$ & $\mathrm{R}$ & $S$ & $\mathrm{R}$ & $\mathrm{R}$ & $\mathrm{R}$ & $\mathrm{R}$ & $\mathrm{R}$ & $\mathrm{R}$ & $S$ & $\mathrm{R}$ \\
\hline Erthyromicin & $\mathrm{R}$ & S & $\mathrm{R}$ & $\mathrm{R}$ & $\mathrm{R}$ & $\mathrm{R}$ & $\mathrm{R}$ & $\mathrm{R}$ & $\mathrm{R}$ & $\mathrm{R}$ & $\mathrm{R}$ & $\mathrm{R}$ & $\mathrm{R}$ & $\mathrm{R}$ & $\mathrm{R}$ \\
\hline Cefuroxime & $\mathrm{S}$ & $S$ & $\mathrm{R}$ & $\mathrm{R}$ & $\mathrm{R}$ & $\mathrm{R}$ & S & $\mathrm{R}$ & $\mathrm{R}$ & $\mathrm{R}$ & $\mathrm{R}$ & $\mathrm{R}$ & $\mathrm{R}$ & $\mathrm{R}$ & $\mathrm{R}$ \\
\hline Tobramycin & $\mathrm{R}$ & S & $S$ & $\mathrm{R}$ & $\mathrm{R}$ & $\mathrm{R}$ & $\mathrm{R}$ & $\mathrm{R}$ & $\mathrm{R}$ & $\mathrm{R}$ & $\mathrm{R}$ & $\mathrm{R}$ & $\mathrm{R}$ & $\mathrm{R}$ & $\mathrm{R}$ \\
\hline Ampicillin & $\mathrm{R}$ & $\mathrm{S}$ & $\mathrm{R}$ & $\mathrm{R}$ & $\mathrm{R}$ & $\mathrm{S}$ & $\mathrm{S}$ & $\mathrm{R}$ & $\mathrm{R}$ & $\mathrm{R}$ & $\mathrm{S}$ & $\mathrm{R}$ & $\mathrm{R}$ & $\mathrm{R}$ & $\mathrm{R}$ \\
\hline Tetracycline & $\mathrm{R}$ & $\mathrm{S}$ & $\mathrm{S}$ & $\mathrm{S}$ & $\mathrm{S}$ & $\mathrm{R}$ & $\mathrm{R}$ & $\mathrm{S}$ & $\mathrm{R}$ & $\mathrm{R}$ & $\mathrm{S}$ & $\mathrm{R}$ & $\mathrm{R}$ & $\mathrm{s}$ & $\mathrm{R}$ \\
\hline Ceftriazone & $\mathrm{S}$ & S & $S$ & $\mathrm{R}$ & $S$ & $\mathrm{R}$ & S & $\mathrm{R}$ & $\mathrm{R}$ & $\mathrm{R}$ & $S$ & $\mathrm{R}$ & $\mathrm{R}$ & $\mathrm{R}$ & $S$ \\
\hline Polmycin & $\mathrm{S}$ & $\mathrm{S}$ & $\mathrm{R}$ & $\mathrm{R}$ & $\mathrm{R}$ & $\mathrm{R}$ & $\mathrm{S}$ & $\mathrm{R}$ & $\mathrm{R}$ & $\mathrm{R}$ & $\mathrm{R}$ & $\mathrm{R}$ & $\mathrm{R}$ & $\mathrm{R}$ & $\mathrm{R}$ \\
\hline Nitrofurantin & $\mathrm{R}$ & $\mathrm{R}$ & $\mathrm{R}$ & S & $\mathrm{R}$ & $\mathrm{R}$ & $\mathrm{R}$ & $\mathrm{R}$ & $\mathrm{R}$ & $\mathrm{R}$ & $\mathrm{R}$ & $\mathrm{R}$ & $\mathrm{R}$ & $\mathrm{R}$ & $\mathrm{R}$ \\
\hline Rifampicin & $\mathrm{S}$ & $S$ & $\mathrm{R}$ & $S$ & S & $\mathrm{R}$ & S & $\mathrm{R}$ & $\mathrm{R}$ & $\mathrm{R}$ & $\mathrm{R}$ & $\mathrm{R}$ & $\mathrm{R}$ & $S$ & $\mathrm{R}$ \\
\hline Clindamycin & $\mathrm{R}$ & $\mathrm{R}$ & $\mathrm{R}$ & $\mathrm{R}$ & $S$ & $\mathrm{R}$ & $\mathrm{R}$ & $\mathrm{R}$ & $\mathrm{R}$ & $\mathrm{R}$ & $\mathrm{R}$ & $\mathrm{R}$ & $\mathrm{R}$ & $\mathrm{R}$ & $\mathrm{R}$ \\
\hline Netillin & $\mathrm{S}$ & S & $S$ & S & $S$ & $\mathrm{R}$ & S & $\mathrm{R}$ & $\mathrm{R}$ & $\mathrm{R}$ & S & $\mathrm{R}$ & $S$ & $S$ & $\mathrm{R}$ \\
\hline Ceftrazidime & $\mathrm{R}$ & $S$ & $\mathrm{R}$ & $\mathrm{R}$ & $S$ & $\mathrm{R}$ & $\mathrm{R}$ & $\mathrm{R}$ & $\mathrm{R}$ & $\mathrm{R}$ & $\mathrm{R}$ & $\mathrm{R}$ & $\mathrm{R}$ & $\mathrm{R}$ & $\mathrm{R}$ \\
\hline Novobiocin & S & $S$ & $\mathrm{~S}$ & $S$ & $S$ & $\mathrm{R}$ & S & $\mathrm{R}$ & $\mathrm{R}$ & $S$ & S & $\mathrm{R}$ & $S$ & $\mathrm{R}$ & $\mathrm{R}$ \\
\hline Aztreonam & $\mathrm{R}$ & $\mathrm{R}$ & $\mathrm{R}$ & $\mathrm{R}$ & $\mathrm{R}$ & $\mathrm{R}$ & $\mathrm{R}$ & $\mathrm{R}$ & $\mathrm{R}$ & $\mathrm{R}$ & $\mathrm{R}$ & $\mathrm{R}$ & $\mathrm{R}$ & $\mathrm{R}$ & $\mathrm{R}$ \\
\hline Cephotaxine & $\mathrm{S}$ & $S$ & $S$ & $S$ & $S$ & $\mathrm{R}$ & S & $S$ & $\mathrm{R}$ & $\mathrm{R}$ & S & $\mathrm{R}$ & $\mathrm{R}$ & S & $\mathrm{R}$ \\
\hline Chloramphenicol & $\mathrm{R}$ & $\mathrm{R}$ & $\mathrm{R}$ & $\mathrm{S}$ & $\mathrm{R}$ & $\mathrm{R}$ & $\mathrm{R}$ & $\mathrm{R}$ & $\mathrm{R}$ & $\mathrm{R}$ & $\mathrm{R}$ & $\mathrm{R}$ & $\mathrm{R}$ & $\mathrm{R}$ & $\mathrm{R}$ \\
\hline Streptomycin & $\mathrm{R}$ & $\mathrm{R}$ & $\mathrm{R}$ & $\mathrm{R}$ & $\mathrm{R}$ & $\mathrm{R}$ & $\mathrm{R}$ & $\mathrm{R}$ & $\mathrm{R}$ & $\mathrm{R}$ & $\mathrm{R}$ & $\mathrm{R}$ & $\mathrm{R}$ & $\mathrm{R}$ & $\mathrm{R}$ \\
\hline Penicillin & $\mathrm{R}$ & $\mathrm{R}$ & $\mathrm{R}$ & $\mathrm{R}$ & $\mathrm{R}$ & $\mathrm{R}$ & $\mathrm{R}$ & $\mathrm{R}$ & $\mathrm{R}$ & $\mathrm{R}$ & $\mathrm{R}$ & $\mathrm{R}$ & $\mathrm{R}$ & $\mathrm{R}$ & $\mathrm{R}$ \\
\hline Methicillin & $\mathrm{R}$ & $\mathrm{R}$ & $\mathrm{R}$ & $\mathrm{R}$ & $\mathrm{R}$ & $\mathrm{R}$ & $\mathrm{R}$ & $\mathrm{R}$ & $\mathrm{R}$ & $\mathrm{R}$ & $\mathrm{R}$ & $\mathrm{R}$ & $\mathrm{R}$ & $\mathrm{R}$ & $\mathrm{R}$ \\
\hline Jancomycin & $\mathrm{R}$ & $\mathrm{R}$ & $\mathrm{R}$ & S & $\mathrm{R}$ & $\mathrm{R}$ & $\mathrm{R}$ & $\mathrm{R}$ & $\mathrm{R}$ & $\mathrm{R}$ & $\mathrm{R}$ & $\mathrm{R}$ & $\mathrm{R}$ & $\mathrm{R}$ & $\mathrm{R}$ \\
\hline Gentamycin & $\mathrm{S}$ & $\mathrm{S}$ & $\mathrm{R}$ & S & $\mathrm{R}$ & $\mathrm{R}$ & $\mathrm{S}$ & $\mathrm{R}$ & $\mathrm{R}$ & $\mathrm{R}$ & $\mathrm{s}$ & $\mathrm{R}$ & S & S & $\mathrm{R}$ \\
\hline Vancomycin & $\mathrm{R}$ & $\mathrm{R}$ & $S$ & $S$ & $\mathrm{R}$ & $\mathrm{R}$ & $\mathrm{R}$ & $\mathrm{R}$ & $\mathrm{R}$ & $\mathrm{R}$ & $\mathrm{R}$ & $\mathrm{R}$ & $\mathrm{R}$ & $\mathrm{R}$ & $\mathrm{R}$ \\
\hline
\end{tabular}

\subsection{GCMS Analysis and Screening of Bioactive Compounds}

The crude extract of secondary metabolites was analyzed with the GCMS technique to identify the possible bioactive compounds' availability. Figure 9 representatively illustrates a sample's GCMS. Figures 10-12 are the segregated compounds (Heterocyclic, Peptides, and Polyketides). Maximum of 
these compounds were found as unidentified or unpublished. Identified compounds were found with structural clarity and mostly equipped with functionally important scaffolds/groups. The confirmed nature allowed us to screen them as the most suitable medications against fungal infections.

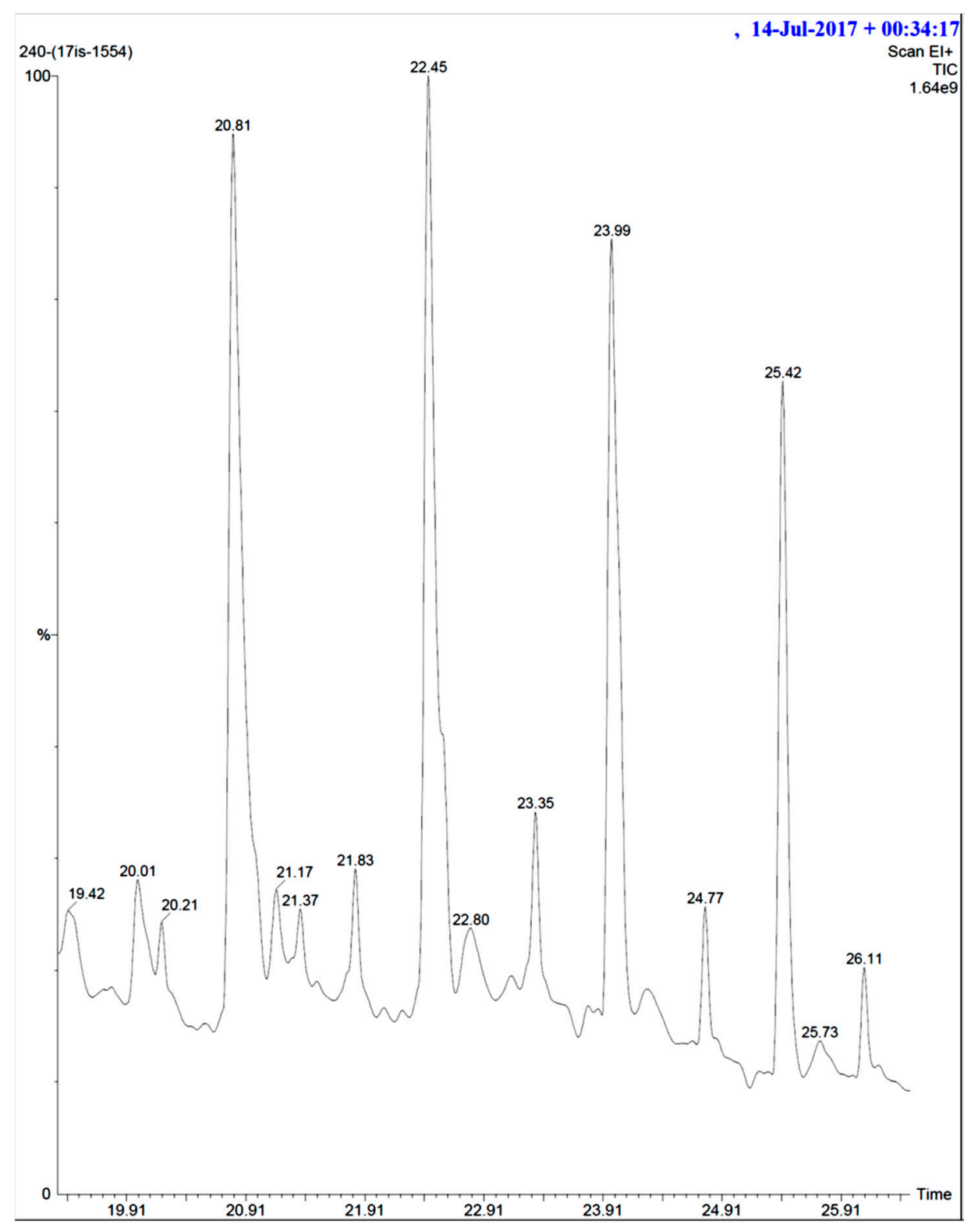

Figure 9. GCMS result of Actinobacteria secondary metabolite from marine mangrove sediment.

\subsection{Pharmacological Property Predictions of Screened Compounds}

In order to find the most suitable antifungal medications, the compounds that were categorized from GCMS studies were predicted for their possible biological activity potentials through Molinspiration and PASS (Figure 13). Among the segregated Heterocyclic (Cpd1-Cpd8) (Figure 10), peptides (Cpd9-Cpd12) (Figure 11), and polyketides (Cpd13-Cpd16) (Figure 12), a significant protease inhibition ability was found especially for peptide and polyketides. Particularly, the Molinspiration predictions revealed the strong Protease inhibitory potentials of all peptides (Cpd9-Cpd12) and polyketides (Cpd13-Cpd16) with a positive score range of 0.3 to 1 . Apart from this, PASS prediction possible activity score of 0.922 (as NADPH peroxidase inhibitor) was found to have been established to the Heterocyclic compound; Cpd1 indicated its potential antifungal medicinal value. The opportunistic 
human fungal pathogen Candida albicans was already proven to use an NADPH oxidase enzyme (NOX) and reactive oxygen species (ROS) to regulate morphogenesis in an animal host $[18,19]$. So, this PASS score is a gateway to evaluate $\mathrm{Cpd} 1$ as a possible antifungal drug.<smiles>CCc1ccc(B2OCC(C(O)CO)O2)cc1</smiles>

1,2-ETHANEDIOL, 1-(2-PHENYL-1,3,2DIOXABOROLAN-4-YL)-, [S-( $\left.\left.\mathrm{R}^{*}, \mathrm{R}^{*}\right)\right]-$

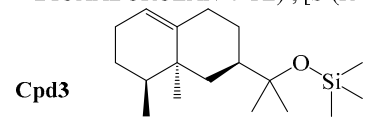

4.BETA.H,5.ALPHA.-EREMOPHIL-1(10)-ENE, 11-(TRIMETHYLSILOXY)-<smiles>CC1(C)CCCC2(C)C1CCC1(C)OC(N)CCC12</smiles>

4A, 7,7,10A-TETRAMETHYLDODECAHYDRO BENZO[F]CHROMEN-3-YLAMINE<smiles>CC(C)(C)OC(=O)N1CC1C(N)=O</smiles>

2-CARBAMOYLAZIRIDINE-1-CARBOXYLIC ACID, T-BUTYL ESTER

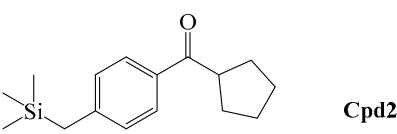

4-(TRIMETHYLSILYLMETHYL)BENZOYLCYCLOPENTANE<smiles>CCCCCOC(=O)c1ccc(NC(=O)/C=C/c2ccc(OC)c(OC)c2)cc1</smiles>
ACRYLOYLAMINO]-, PENTYL ESTEr

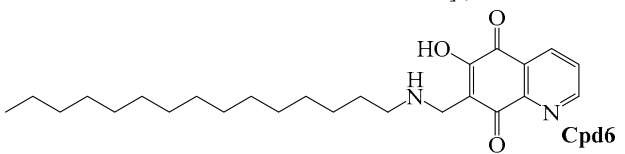

6-HYDROXY-7-((PENTADECYLAMINO)METHYL)

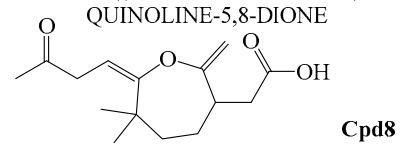

ACETIC ACID, 6,6-DIMETHYL-2-METHYLENE-7(3-OXOBUTYLIDENE)OXEPAN-3-YL

Figure 10. Heterocyclic compounds.

L-ARGININE, METHYL ESTER<smiles>COC(=O)[C@H](N)C(C)CCNC(=N)N</smiles><smiles>COC(=O)NC(C)C(=O)NCC#N</smiles>

\section{Cpd11}

METHYL (1-((CYANOMETHYL)AMINO) -1-OXOPROPAN-2-YL)CARBAMATE
L-LEUCYL-GLYCYL-L-LEUCINE<smiles>CCSC1CN(C(=O)[C@H](C)NC(=O)C(C)N)C(=O)N(C(C)(C)CNC(=O)C[C@H](CC(C)C)C(=O)O)N1</smiles>

T-BUTOXYCARBONYLALANYL-ALANYL AMINO-2-(ETHYLTHIO)-2-IMINOETHANE

Figure 11. Peptide compounds.

GALACTOSE, 4,6-O-OCTYLIDENE-<smiles>CCCCCCCC1OC[C@@H](O)[C@H]([C@H](O)[C@H](O)C=O)O1</smiles>

D-GLUCOPYRANOSE, 4,6-O-OCTYLIDENE-<smiles>CCCCCCCC1OCC2OC(O)[C@H](O)[C@H](O)[C@H]2O1</smiles>

.ALPHA.-D-MANNOFURANOSIDE, 1-NONYL-<smiles>CCCCCCCCCOC1OC([C@H](O)CO)[C@H](O)[C@H]1O</smiles>

.ALPHA.-D-MANNOFURANOSIDE, 1-O-DECYL-<smiles>CCCCCOC1OC([C@H](O)CO)C(O)C1O</smiles>

Figure 12. Polyketide compounds. 


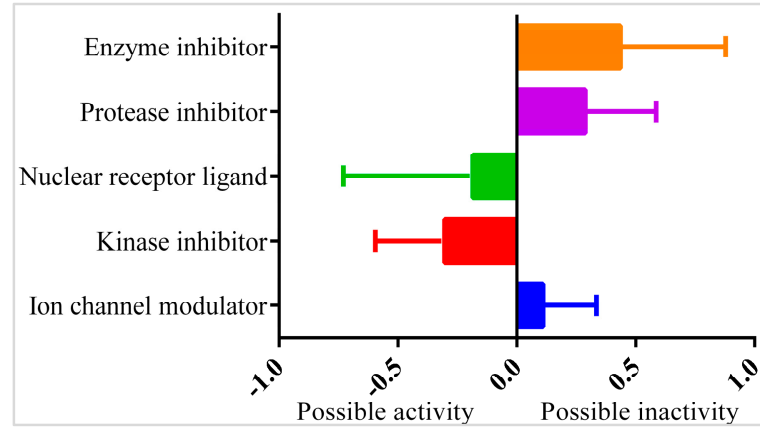

(a)

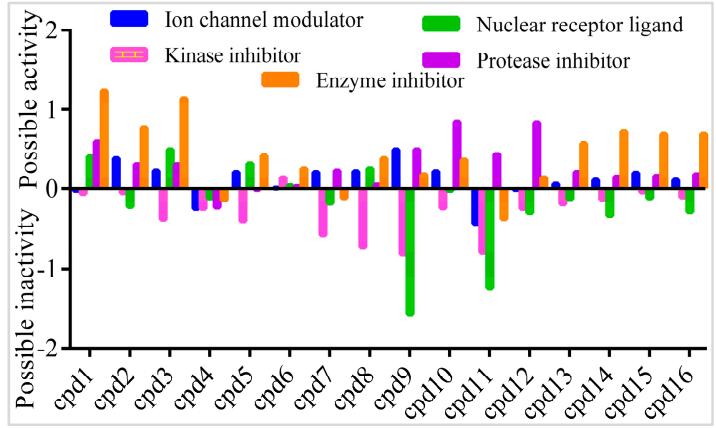

(b)

Figure 13. Bioactivity prediction results of isolated compounds from Actinobacteria: (a) Overall bioactivity of the compounds (b) Individual bioactivity of the compound.

\section{Discussion}

Mangrove ecosystem remains untapped and thus seems to be a promising source as a rare actinobacteria enabling pipeline of novel natural products. Marine actinobacteria are well known to be valuable antifungal drug sources [20]. The present study has focused on targeting the biosynthetic genes in actinobacteria from the Andaman Islands, for production of novel antifungals. In this study, a potential strain has been identified from mangrove soil sediments which exhibits excellent inhibitory activity against clinical C. albicans. Biosynthetic genetic assessment was performed for the identified strain and then bioactive metabolites were extracted. To the best of our knowledge, this is the first study to evaluate the antifungal activity of Actinobacteria isolated from the Andaman Islands, against clinical pathogens of $C$. albicans. There are only a few reports about the actinobacteria from the Andaman islands, India which focuses on screening of enzymatic activity [21], antibacterial activity [22], and antifungal activity against multidrug resistant pathogens (C. albicans) [23]. Significantly, the study opens a new horizon by providing insights into the diversity and bio-potential of prominent strains isolated from mangrove ecosystem of the Andaman Islands.

Among all fungi, C. albicans, asymptomatically inhabits and affects various systems of healthy human beings and it is the most common microbe found in the oral and gastrointestinal tract in 40-60\% cases of Candidiasis [24,25]. The occurrence of candidiasis even in HIV-infected and cancer patients, seems to clearly depict the increasing threat alarm [26]. Only rare species of Candida cause candidiasis due to the uncontrolled growth of fungus [27]. Henceforth, there is a thrust area in finding the prospective natural compounds against fungi.

Genes coding for secondary metabolites are highly conserved in the phylum of actinobacteria. The gene cluster analysis affords to identify the positive strains for the production of novel metabolites [28]. In this study, PCR screening for biosynthetic genes of the strains was performed. Degenerate PCR primers targeting conserved motifs in these genes helped to infer the biosynthetic potential of the strains [11]. The results revealed the existence of biosynthetic genes (PKS type I and II, NRPS), which helped in prioritizing the strains with inherent potential to synthesize secondary metabolites. NRPS positive strains are widely present, however, PKS type I and II are less frequent due to the lack of genes in those strains or less similarity of degenerate primers used in unusual domains present in the corresponding genes [29]. Among all the PKS and NRPS positive strains screened, only VITGAP240 and VITGAP241 were found to be potentially active against clinical isolates of C. albicans. Though gene-metabolite correlation helps in prioritizing the strains, the study indicates that all genetically positive strains were not functionally active because of cryptic-silent gene clusters [11]. Fermentation broths of two strains, namely VITGAP240 and VITGAP241, exhibited bioactivity against clinical isolates of C. albicans.

Among various compounds identified from the strain VITGAP241 crude extract through GC-MS analysis, only 16 compounds were selected based on the protease activity (generally acting as 
antifungal agents) [30] prediction using Molinspiration and PASS online tools. The obtained secondary metabolites of Actinomycetales highlights a potential source of numerous novel therapeutics with antifungal, antibacterial, antiviral, antiparasitic and antitumour etc. properties [28]. The compounds were grouped into polyketides, peptides and heterocyclic compounds. To the best of our knowledge the identified compounds from the strain Streptomyces sp. VITGAP241 have been reported for the first time by highlighting their extensive potential activity.

In addition to that, among the identified compounds, Cpd10 (L-Leucyl-Glycyl-L-Leucine) was found to have a carboxylic acid group which ensures the assured exchange of electrons to form hydrogen bonds within a minimal $\AA$ range. The anticipated interaction to achieve maximum expected therapeutic value, compound/drug dissolution, pharmacokinetic/pharmacodynamics and ADMET properties are made easy due to this facilitated functional group availability. Importantly, the Ligand-Receptor combinations requires -SH complex to inhibit the corresponding enzymes that are involved in the disease generation and development [31]. Hence, Cpd12 (T-Butoxycarbonylalanyl-Alanyl-Amino-2-(Ethylthio)-2-Aminoethane) was found to have established with a -S unit along with all other essential functional units which includes three carbonyl, methoxy, amino and methyl. Moreover, Cpd16 has the maximum protease inhibition activity of all other identified compounds. Further, polyketides that are widely substituted with $-\mathrm{OH},-\mathrm{O},-\mathrm{CHO}$ are normally involved in the bi-functional including electron donation and acceptation. This facilitates the internal temporary bridging between the compounds and the target proteins which depicts the promising medicinal value. The compounds Cpd13 (Galactose, 4,6-o-octylidene-), Cpd14 (.Alpha.-d-mannofuranoside, 1-nonyl-), Cpd15 (D-Glucopyranose, 4,6-o-octylidene-) and Cpd16 (.Alpha.-d-mannofuranoside, 1-o-decyl-) were commonly found to have - $\mathrm{OH},-\mathrm{O},-\mathrm{CHO}$ as their core functional units. The other group, Peptides, well-known protease inhibitors, were also established with $-\mathrm{S},-\mathrm{NH},-\mathrm{O},-\mathrm{OH},-\mathrm{OMe}$ and $-\mathrm{Me}$. These are the best examples for mixed functional substituents i.e., electron donor, acceptor, functionally activators and deactivators that makes the compounds have a balanced interaction between the target proteins.

The strains were further allowed to assess the drug resistance which reveals the significant activity against the antibiotics. In particular, VITGAP240 exhibits the resistance against 17 antibiotics, whereas VITGAP241 exibits resistance to 14 antibiotics. This clearly indicates that these two bioactive strains encompass a wide spectrum of antimicrobials with their putative activity. The presence of multiple biosynthetic genes could be involved in the production of various compounds which shows the potential drug resistance [32]. Further investigation about the bioactive ingredients of potential strains shed light in understanding the relation between the biosynthetic gene and metabolites for the scientific community. Concomitantly, the strain Streptomyces sp. VITGAP241 harbor great potential to synthesize metabolites which could contribute to a large extent in drug discovery.

\section{Materials and Methods}

\subsection{Isolation of Marine Mangrove Actinobacteria}

Marine mangrove sediments were collected aseptically in sterile plastic containers from Muthupet (3 October 2015) and Andaman, Nicobar Islands (20 February 2016), India. The collected samples were transferred to the lab, stored at $4{ }^{\circ} \mathrm{C}$ and processed within 2-3 days. One gram of collected wet sediment was suspended in $99 \mathrm{~mL}$ of $50 \%$ sterile sea water and kept for shaking at $120 \mathrm{rpm}$ for $3 \mathrm{~h}$ in rotary shaker. The enriched sediment sample was subjected to serial logarithmic dilution in $0.8 \%$ saline down to $10^{-4}$. $0.1 \mathrm{~mL}$ of aliquot from each dilution; it was then plated in Starch casein agar, Actinomycetes isolation agar, International Streptomycetes project-2 and Bennett's agar medium and incubated at $28^{\circ} \mathrm{C}$ for $7-10$ days [33]. Pre-treatment of the sediment samples was also done to avoid fungal growth, wherein, the sediment samples after a brief period of air drying, were subjected to heating at $65^{\circ} \mathrm{C}$ for $20 \mathrm{~min}$ [34]. The pre-treated sediment samples were then processed in the same way as wet sediment processing. Actinomycetes were initially recognized by traditional 
morphological criteria including their characteristic leathery colonies, pigmentation including chalky white appearance, morphology of substrate and aerial hyphae [35].

\subsection{Genomic DNA Extraction for Identification Through $16 S$ rRNA Sequencing}

The isolates obtained from the sediments were processed for the genomic DNA extraction, using HiPurA $^{\mathrm{TM}}$ Streptomyces DNA Purification Kit (MB527, Himedia, Mumbai, India) for immediate use or for storage at $-20^{\circ} \mathrm{C}$. Concentration and purity of the extracted DNA was then evaluated by running on Agarose gel and by NanoDrop (Thermo Scientific) readings.

\subsection{Amplification of $16 S$ rRNA Gene and Sequencing}

The genomic DNA obtained from the actinobacterial strains was further subjected to PCR amplification of 16S rRNA gene using the primers 27F-(5'-AGAGTTTGATCCTGGCTCAG- $3^{\prime}$ ) and 1492R-(5'-ACGGCTACCTTGTTACGACTT-3') [36]. The PCR mixture consisted of $5 \mu \mathrm{L}$ of master mix (Ampliqon), $0.5 \mu \mathrm{L}$ each of forward and reverse primer, $3.5 \mu \mathrm{L}$ of $\mathrm{ddH}_{2} \mathrm{O}, 0.5 \mu \mathrm{L}$ of template DNA $(20 \mathrm{ng} / \mu \mathrm{L})$ and the conditions were as follows: initial denaturation at $94{ }^{\circ} \mathrm{C}$ for $8 \mathrm{~min} ; 30$ cycles at $94{ }^{\circ} \mathrm{C}$ for $1 \mathrm{~min}, 57^{\circ} \mathrm{C}$ for $1 \mathrm{~min}$, and $72{ }^{\circ} \mathrm{C}$ for $2 \mathrm{~min}$; and a final 8-min extension at $72{ }^{\circ} \mathrm{C}$. Further detection of the PCR product was done by agarose gel electrophoresis. The purified PCR products were sequenced by MacroGen Co. (Seoul, Korea). Phylogeny prediction was done using MEGA 4.0. DNA sequences were deposited in NCBI with following accession numbers: KY608546-KY608550, KY608585-KY608609.

\subsection{PCR Screening for Biosynthetic Genes}

PCR amplifications with final volume of $100 \mu \mathrm{L}$ were performed with following primers: PKS type I degenerate primers, K1F-(5'-TSAAGTCSAACATCGGBCA- $\left.3^{\prime}\right)$ and M6R-( $5^{\prime}$-CGCAGGTTSCSGTACCAGTA- $\left.3^{\prime}\right)$ using the following conditions: initial denaturation of $95{ }^{\circ} \mathrm{C}$ for $10 \mathrm{~min} ; 35$ cycles of $95^{\circ} \mathrm{C}$ for $30 \mathrm{~s}, 55^{\circ} \mathrm{C}$ for $60 \mathrm{~s}$, and $72{ }^{\circ} \mathrm{C}$ for $2 \mathrm{~min}$; and a final extension at $72{ }^{\circ} \mathrm{C}$ for $10 \mathrm{~min}$, PKS type II degenerate primers KS $\alpha \mathrm{F}-\left(5^{\prime}\right.$-TSGRCTACRTCAACGCSCACGG- $\left.3^{\prime}\right)$ and KS $\beta R$ - $\left(5^{\prime}\right.$-TACSAGTCSWTCGCCTGGTTC- $\left.3^{\prime}\right)$ using the following conditions: initial denaturation of $95{ }^{\circ} \mathrm{C}$ for $10 \mathrm{~min}$; 30 cycles of $95^{\circ} \mathrm{C}$ for $30 \mathrm{~s}, 58^{\circ} \mathrm{C}$ for $30 \mathrm{~s}$, and $72{ }^{\circ} \mathrm{C}$ for $45 \mathrm{~s}$; and a final extension at $72{ }^{\circ} \mathrm{C}$ for $10 \mathrm{~min}$, for NRPS, A3F-(5'-GCSTACSYSATSTACACSTCSGG-3') and A7R-( $5^{\prime}$-SASGTCVCCSGTSCGGTAS- $\left.3^{\prime}\right)$ using the following conditions: initial denaturation of $95^{\circ} \mathrm{C}$ for $10 \mathrm{~min}$; $35 \mathrm{cycles}$ of $95^{\circ} \mathrm{C}$ for $30 \mathrm{~s}, 61^{\circ} \mathrm{C}$ for $45 \mathrm{~s}$, and $72{ }^{\circ} \mathrm{C}$ for $1 \mathrm{~min}$; and a final extension at $72{ }^{\circ} \mathrm{C}$ for $10 \mathrm{~min}[37,38]$. Amplified fragments were then analyzed using $100 \mathrm{bp}$ DNA ladder (HiMedia) in agarose gel (1.2\%). The biosynthetic genes of the bioactive isolates were sequenced by MacroGen Co. (Seoul, Korea). The sequences were deposited in NCBI with following accession numbers: PKS type I-VITGAP240 (MG564705), VITGAP241 (MG564706), PKS type II-VITGAP240 (MG564711), VITGAP241 (MG564712), NRPS-VITGAP241 (MG564713).

\subsection{Phylogenetic Analysis of the Strains}

For the phylogenetic assessment, the gene sequences were aligned in Alignment Explorer of MEGA software, version 4 [39] using ClustalW preference. The trimming and verification of the sequence alignment were carried out by utilizing the MUSCLE (UPGMA) algorithm [40]. The neighbour-Joining [41] and maximum-parsimony methods were used to compute the evolutionary distances. Bootstrap analyses were performed with 1000 replications to evaluate the tree robustness [42].

\subsection{Evaluation of Antifungal Activity}

Actinobacterial strains harboring the biosynthetic genes were selected for evaluation of anti-candidal activity by agar well diffusion method [43]. 16 clinical isolates of C. albicans were obtained from diagnostic centers of Tiruchirappalli, Tamil Nadu. These isolates were inoculated in 
Sabouraud dextrose broth and incubated for growth until $10^{6} \mathrm{CFU} / \mathrm{mL}$ (0.5 McFarland) was obtained. $100 \mu \mathrm{L}$ of the fungal suspensions were seeded onto Sabouraud dextrose agar plates and wells of $6 \mathrm{~mm}$ diameter were punched using sterile borer. The actinobacterial strains were inoculated in Starch casein broth and incubated at $28^{\circ} \mathrm{C}, 150 \mathrm{rpm}$ for 7 days. The culture supernatant was then collected after centrifugation of the culture at 10,000 rpm for $10 \mathrm{~min}$. The culture supernatant was extracted with equal amount of ethyl acetate and subsequently evaporated to obtain the crude extracts. $50 \mu \mathrm{L}$ of the actinobacterial culture extract were added to the wells and tested for anti-candidal activity. The plates were incubated at $28{ }^{\circ} \mathrm{C}$ for $24-48 \mathrm{~h}$. The experiments were performed in triplicates.

\subsection{Antibiotic Susceptibility Test}

Standard antibiotic discs (30 mcg/disc) were used to evaluate the antibiotic sensitivity blueprint of the isolates. The potential isolates were inoculated in starch casein broth and incubated at $28 \pm 2{ }^{\circ} \mathrm{C}$, $150 \mathrm{rpm}$ for 7 days. The grown cultures were then plated on Starch casein agar plates and the antibiotic discs were placed on the top of the spread culture. The plates were then incubated at $28{ }^{\circ} \mathrm{C}$ for 24-48 h. The plates were then observed for the occurrence of inhibition zone and the diameters were measured [44]. Based on the zone formed, the isolates were considered either as susceptible (S), or resistant $(\mathrm{R})$ for the antibiotics tested.

\subsection{GCMS Results and Screening of Pharmacologically Important Bioactive Compounds}

In order to screen the bioactive or medicinally important secondary metabolite compounds, the Gas Chromatography Mass Spectrometry (GCMS) analysis was executed for the crude extract followed by the Thin Layer Chromatography (TLC) confirmations. TLC was performed using pre-coated silica-in alumina plate $\mathrm{F}_{254}$ (Merck) to separate the individual compounds from the non-volatile mixture (crude extract of the Actinomycetes sp.). Crude samples were spotted on the TLC plates and eluted from 0 to $100 \%$ n-Hexane/Ethyl acetate. The obtained spots were analyzed (TLC chamber) and noted for easy elution at suitable elution \% using $n$-Hexane/Ethyl acetate (2:8) of individual spot via column chromatography. To determine the eluted individual compounds, GCMS analysis was carried-out using the Clarus 680 GC fused silica column, packed with Elite-5MS (5\% biphenyl 95\% dimethylpolysiloxane, $30 \mathrm{~m} \times 0.25 \mathrm{~mm}$ ID $\times 250 \mu \mathrm{m} \mathrm{df}$ ) and the components were separated using Helium as carrier gas at a constant flow of $1 \mathrm{~mL} / \mathrm{min}$. The injector temperature was set at $260{ }^{\circ} \mathrm{C}$ during the chromatographic run. The $1 \mu \mathrm{L}$ of extract sample was injected into the instrument. The oven temperature was as follows: $60{ }^{\circ} \mathrm{C}(2 \mathrm{~min})$; followed by $300{ }^{\circ} \mathrm{C}$ at the rate of $10{ }^{\circ} \mathrm{C} \mathrm{min}-1$; and $300^{\circ} \mathrm{C}$, where it was held for $6 \mathrm{~min}$. The mass detector conditions were: transfer line temperature $240{ }^{\circ} \mathrm{C}$; ion source temperature $240{ }^{\circ} \mathrm{C}$; and ionization mode electron impact at $70 \mathrm{eV}$, a scan time $0.2 \mathrm{~s}$ and scan interval of $0.1 \mathrm{~s}$. The spectrums of the components were compared with the database of spectrum of known components stored in the GCMS NIST (2008) library. ChemDraw (Version 15.0) was used to elucidate the structural confirmations of the bioactive compounds. The bioactive materials that were isolated from Actinomycetes sp. were categorized according the availability of functional groups under three major types i.e., polyketides, peptides and heterocyclic compounds. Their physical and chemical properties were unveiled.

\subsection{Pharmacological Property Predictions of Screened Compounds}

The categorized compounds from GCMS analysis were predicted for their possible biological activity potentials through Molinspiration and PASS [45,46].

\section{Conclusions}

Marine actinobacteria are known to produce many secondary metabolites and its diversity in Indian marine ecosystem is being explored. Our present study evidently revealed the potential of actinobacteria isolated from Indian marine environments which allow the synthesis of a wide spectrum of antifungal compounds. A wide spectrum of the characterized bioactive compounds 
were the products of gene clusters that expressed coordinately. Moreover, the importance of PKS and NRPS genes for the expression of antifungal activity in marine actinobacteria has been established. Further, we found that the PCR based prescreening of target genes encoding for bioactive compound synthesis is one of the effective approaches for the detection of novel and active secondary metabolites. There are many questions with regard to the evolution and distribution of actinobacteria in the marine ecosystem, as well as unique sources for the isolation of novel actinobacteria which produce bioactive metabolites; this study depicts the potential of actinobacteria to synthesis bioactive compounds with the promising antifungal activity. Hence, further characterization of antifungal compounds generated by these actinobacteria could solve the emerging the problem of antibiotic resistance in C. albicans. Future studies should include isolation, identification and characterization of the bioactive compounds responsible for the bioactivity; insights about molecular interaction (between target receptor and potentially identified compounds); a suitable in vitro or in vivo model to validate medicinal effects of the compounds; establishment of Structure-Activity Relationship and finally ADMET, PK/PD and druggability validations.

Acknowledgments: The authors gratefully acknowledge VIT University, Vellore for the support through Seed Grant for Research. We also thank A. Manikandan, Department of Biotechnology, VIT University for his valuable suggestion in separation of bioactive compounds and their bioactivity predictions of compounds. VV acknowledges FCT Project UID/Multi/04423/2013 and by the Structured Program of R\&D\&I INNOVMAR-Innovation and Sustainability in the Management and Exploitation of Marine Resources (reference NORTE-01-0145-FEDER-000035, Research Line NOVELMAR), funded by the Northern Regional Operational Program (NORTE2020) through the European Regional Development Fund (ERDF).

Author Contributions: J.G.S.P.K. and A.G. were responsible for the experiment design, operation of the biology experiments and manuscript preparation; J.G.S.P.K. was responsible for preparation of experimental samples and data processing, K.M.G. and V.V. guided the whole experiment and revised the manuscript.

Conflicts of Interest: The authors declare no conflict of interest.

\section{References}

1. Cragg, G.M.; Newman, D.J. Natural products: A continuing source of novel drug leads. Biochim. Biophys. Acta 2013, 1830, 3670-3695. [CrossRef] [PubMed]

2. Bérdy, J. Thoughts and facts about antibiotics: Where we are now and where we are heading. J. Antibiot. (Tokyo) 2012, 65, 385-395. [CrossRef] [PubMed]

3. Demain, A.L.; Sanchez, S. Microbial drug discovery: 80 Years of progress. J. Antibiot. (Tokyo) 2009, 62, 5-16. [CrossRef] [PubMed]

4. Zotchev, S.B. Marine actinomycetes as an emerging resource for the drug development pipelines. J. Biotechnol. 2012, 158, 168-175. [CrossRef] [PubMed]

5. Tan, L.T.H.; Chan, K.G.; Lee, L.H.; Goh, B.H. Streptomyces bacteria as potential probiotics in aquaculture. Front. Microbiol. 2016, 7, 1-8. [CrossRef] [PubMed]

6. Nikolouli, K.; Mossialos, D. Bioactive compounds synthesized by non-ribosomal peptide synthetases and type-I polyketide synthases discovered through genome-mining and metagenomics. Biotechnol. Lett. 2012, 34, 1393-1403. [CrossRef] [PubMed]

7. Weissman, K.J. Chapter 1 Introduction to Polyketide Biosynthesis. Methods Enzymol. 2009, 459, 3-16. [PubMed]

8. Katz, L.; Donadio, S. Polyketide Synthesis: Prospects for Hybrid Antibiotics. Annu. Rev. Microbiol. 1993, 47, 875-912. [CrossRef] [PubMed]

9. Strieker, M.; Tanović, A.; Marahiel, M.A. Nonribosomal peptide synthetases: Structures and dynamics. Curr. Opin. Struct. Biol. 2010, 20, 234-240. [CrossRef] [PubMed]

10. Ayuso-Sacido, A.; Genilloud, O. New PCR primers for the screening of NRPS and PKS-I systems in actinomycetes: Detection and distribution of these biosynthetic gene sequences in major taxonomic groups. Microb. Ecol. 2005, 49, 10-24. [CrossRef] [PubMed]

11. Wang, H.X.; Chen, Y.Y.; Ge, L.; Fang, T.T.; Meng, J.; Liu, Z.; Fang, X.Y.; Ni, S.; Lin, C.; Wu, Y.Y.; et al. PCR screening reveals considerable unexploited biosynthetic potential of ansamycins and a mysterious 
family of AHBA-containing natural products in actinomycetes. J. Appl. Microbiol. 2013, 115, 77-85. [CrossRef] [PubMed]

12. Fischbach, M.A.; Walsh, C.T. Assembly-line enzymology for polyketide and nonribosomal peptide antibiotics: Logic machinery, and mechanisms. Chem. Rev. 2006, 106, 3468-3496. [CrossRef] [PubMed]

13. Iii, J.E.C. Impact of $16 \mathrm{~S}$ rRNA Gene Sequence Analysis for Identification of Bacteria on Clinical Microbiology and Infectious Diseases. Clin. Microbiol. Rev. 2004, 17, 840-862. [CrossRef]

14. Azman, A.S.; Othman, I.; Velu, S.S.; Chan, K.G.; Lee, L.H. Mangrove rare actinobacteria: Taxonomy, natural compound, and discovery of bioactivity. Front. Microbiol. 2015, 6, 1-15. [CrossRef] [PubMed]

15. Emerson, R.; Procópio, D.L.; Reis, I.; Kassawara, M.; Lúcio, J.; Azevedo, D.; Magali, J.; Araújo, D. Review article Antibiotics produced by Streptomyces. Br. J. Infect. Dis. 2012, 16, 466-471. [CrossRef]

16. Keikha, N.; Mousavi, S.A.A.; Nakhaei, A.R.; Yadegari, M.H.; Bonjar, G.H.S.; Amiri, S. In vitro evaluation of enzymatic and antifungal activities of soil-actinomycetes isolates and their molecular identification by PCR. Jundishapur J. Microbiol. 2015, 8, 1-6. [CrossRef]

17. Kamjam, M.; Sivalingam, P.; Deng, Z.; Hong, K. Deep Sea Actinomycetes and Their Secondary Metabolites. Front. Microbiol. 2017, 8. [CrossRef] [PubMed]

18. Rossi, D.C.P.; Gleason, J.E.; Sanchez, H.; Schatzman, S.S.; Culbertson, M.; Johnson, C.J.; Mcnees, C.A.; Coelho, C.; Nett, E.; Andes, D.R.; et al. Candida albicans FRE8 encodes a member of the NADPH oxidase family that produces a burst of ROS during fungal morphogenesis. PLoS Pathog. 2017, 13, e1006763. [CrossRef] [PubMed]

19. Brothers, K.M.; Gratacap, R.L.; Barker, S.E.; Newman, Z.R.; Norum, A.; Wheeler, R.T. NADPH Oxidase-Driven Phagocyte Recruitment Controls Candida albicans Filamentous Growth and Prevents Mortality. PLoS Pathog. 2013, 9. [CrossRef] [PubMed]

20. Lohse, M.B.; Gulati, M.; Johnson, A.D.; Nobile, C.J. Development and regulation of single- and multi-species Candida albicans biofilms. Nat. Rev. Microbiol. 2017. [CrossRef] [PubMed]

21. Meena, B.; Rajan, L.A.; Vinithkumar, N.V.; Kirubagaran, R. Novel marine actinobacteria from emerald Andaman \& Nicobar Islands: A prospective source for industrial and pharmaceutical byproducts. BMC Microbiol. 2013, 13, 145. [CrossRef]

22. Baskaran, R.; Vijayakumar, R.; Mohan, P.M. Enrichment method for the isolation of bioactive actinomycetes from mangrove sediments of Andaman Islands, India. Malays. J. Microbiol. 2011, 7, 26-32. [CrossRef]

23. Das, A.; Bhattacharya, S.; Yegoup, A.; Mohammed, H. In vitro Antimicrobial Activity and Characterization of Mangrove Isolates of Streptomycetes Effective against Bacteria and Fungi of Nosocomial Origin. Braz. Arch. Biol. Technol. 2014, 57, 349-356. [CrossRef]

24. Erdogan, A.; Rao, S.S.C. Small Intestinal Fungal Overgrowth. Curr. Gastroenterol. Rep. 2015, 17, 1-7. [CrossRef] [PubMed]

25. Martins, N.; Ferreira, I.C.F.R.; Barros, L.; Silva, S.; Henriques, M. Candidiasis: Predisposing Factors, Prevention, Diagnosis and Alternative Treatment. Mycopathologia 2014, 177, 223-240. [CrossRef] [PubMed]

26. Arendrup, M.C.; Patterson, T.F. Multidrug-Resistant Candida: Epidemiology, Molecular Mechanisms, and Treatment. J. Infect. Dis. 2017, 216, 445-451. [CrossRef] [PubMed]

27. Miceli, M.H.; Díaz, J.A.; Lee, S.A.; Candida, N. Emerging opportunistic yeast infections Emerging yeasts. Lancet Infect. Dis. 2011, 11, 142-151. [CrossRef]

28. Hadjithomas, M.; Chen, I.M.A.; Chu, K.; Ratner, A.; Palaniappan, K.; Szeto, E.; Huang, J.; Reddy, T.B.K.; Cimermančič, P.; Fischbach, M.A.; et al. IMG-ABC: A knowledge base to fuel discovery of biosynthetic gene clusters and novel secondary metabolites. MBio 2015, 6, 1-10. [CrossRef] [PubMed]

29. Meklat, A.; Sabaou, N.; Zitouni, A.; Mathieu, F.; Lebrihi, A. Isolation, taxonomy, and antagonistic properties of halophilic actinomycetes in Saharan soils of Algeria. Appl. Environ. Microbiol. 2011, 77, 6710-6714. [CrossRef] [PubMed]

30. Santos, A.L.; Braga-Silva, L.A. Aspartic Protease Inhibitors as Potential Anti-Candida albicans Drugs: Impacts on Fungal Biology, Virulence and Pathogenesis. Curr. Med. Chem. 2011, 18, 2401-2419.

31. Potter, V.R.; Dubois, K.P. Studies on the mechanism of hydrogen transport in animal tissues: VI. Inhibitor studies with succinic dehydraganase. J. Gen. Physiol. 1943, 26, 391-404. [CrossRef] [PubMed]

32. Fair, R.J.; Tor, Y. Perspectives in Medicinal Chemistry Antibiotics and Bacterial Resistance in the 21st Century. Perspect. Med. Chem. 2014, 6, 25-64. [CrossRef] 
33. Özcan, K.; Aksoy, S.Ç.; Kalkan, O.; Uzel, A.; Hames-Kocabas, E.E.; Bedir, E. Diversity and antibiotic-producing potential of cultivable marine-derived actinomycetes from coastal sediments of Turkey. J. Soils Sediments 2013, 13, 1493-1501. [CrossRef]

34. Seong, C.N.; Choi, J.H.; Baik, K. An improved selective isolation of rare actinomycetes from forest soil. J. Microbiol. 2001, 39, 17-23.

35. Chater, K.F.; Hopwood, D.A. The Biology of Actinomycetes. In The Biology of Actinomycetes; Academic Press: London, UK, 1984; pp. 229-286. ISBN 012289670X.

36. Rainey, F.A.; Ward-Rainey, N.; Kroppenstedt, R.M.; Stackebrandt, E. The genus Nocardiopsis represents a phylogenetically coherent taxon and a distinct actinomycete lineage: Proposal of Nocardiopsaceae fam. nov. Int. J. Syst. Bacteriol. 1996, 46, 1088-1092. [CrossRef] [PubMed]

37. Metsä-Ketelä, M.; Halo, L.; Munukka, E.; Hakala, J.; Mäntsäla, P.; Ylihonko, K. Molecular evolution of aromatic polyketides and comparative sequence analysis of polyketide ketosynthase and 16S ribosomal DNA genes from various Streptomyces species. Appl. Environ. Microbiol. 2002, 68, 4472-4479. [CrossRef] [PubMed]

38. Palomo, S.; González, I.; De La Cruz, M.; Martín, J.; Tormo, J.R.; Anderson, M.; Hill, R.T.; Vicente, F.; Reyes, F.; Genilloud, O. Sponge-derived Kocuria and Micrococcus spp. as sources of the new thiazolyl peptide antibiotic kocurin. Mar. Drugs 2013, 11, 1071-1086. [CrossRef] [PubMed]

39. Tamura, K.; Stecher, G.; Peterson, D.; Filipski, A.; Kumar, S. MEGA6: Molecular evolutionary genetics analysis version 6.0. Mol. Biol. Evol. 2013, 30, 2725-2729. [CrossRef] [PubMed]

40. Edgar, R.C. MUSCLE: Multiple sequence alignment with high accuracy and high throughput. Nucleic Acids Res. 2004, 32, 1792-1797. [CrossRef] [PubMed]

41. Tamura, K.; Nei, M.; Kumar, S. Prospects for inferring very large phylogenies by using the neighbor-joining method. Proc. Natl. Acad. Sci. USA 2004, 101, 11030-11035. [CrossRef] [PubMed]

42. Felsenstein, J.S. Confidence limits on phylogenies: An approach using the bootstrap. Evolution 1985, 39, 783-791. [CrossRef] [PubMed]

43. Saadoun, I.; Muhana, A. Optimal production conditions, extraction, partial purification and characterization of inhibitory compound(s) produced by. Trends Biotechnol. 2008, 2, 402-420.

44. Undabarrena, A.; Beltrametti, F.; Claverías, F.P.; González, M.; Moore, E.R.B.; Seeger, M.; Cámara, B. Exploring the diversity and antimicrobial potential of marine actinobacteria from the Comau Fjord in Northern Patagonia, Chile. Front. Microbiol. 2016, 7. [CrossRef] [PubMed]

45. Jarrahpour, A.; Fathi, J.; Mimouni, M.; Parvez, A. Petra, Osiris and Molinspiration (POM) together as a successful support in drug design: Antibacterial activity and biopharmaceutical characterization of some azo Schiff bases. Med. Chem. Res. 2012, 21, 1984-1990. [CrossRef]

46. Kumaresanetal, S.; Senthilkumar, V.; Stephen, A.; Balakumar, J.S. GC-MS analysis and PASS-assisted prediction of biological activity spectra of extract of Phomopsis sp. isolated from Andrographis paniculata. World J. Pharm. Res. 2015, 4, 1035-1053.

(C) 2018 by the authors. Licensee MDPI, Basel, Switzerland. This article is an open access article distributed under the terms and conditions of the Creative Commons Attribution (CC BY) license (http://creativecommons.org/licenses/by/4.0/). 